\title{
РОЗВИТОК ГНУЧКОСТІ ХРЕБТА У СПОРТСМЕНІВ, ЯКІ ЗАЙМАЮТЬСЯ ПАУЕРЛІФТИНГОМ
}

\author{
Єлизавета Толубенко ${ }^{1 \mathrm{ABCD}}$
}

\author{
${ }^{1}$ Харківський національний педагогічний університет імені Г.С. Сковороди \\ Authors' Contribution: A - Study design; B - Data collection; C - Statistical analysis; D - Manuscript Preparation; E - Funds Collection
}

DOI: $10.17309 / \mathrm{jltm} .2021 .1 .04$

\begin{abstract}
Анотація
Мета дослідження - визначити вплив амплітуди руху на результати жиму лежачи у спортсменів, які займаються пауерліфтингом.

Матеріали і методи. У дослідженні брали участь дві групи по 10 спортсменів, які займаються пауерліфтингом - юнаки віком 19-20 років. У роботі використано такі методи: спостереження, методи теоретичного аналізу та узагальнення, педагогічний експеримент, педагогічне тестування, методи математичної статистики. Дослідження тривали упродовж п’яти місяців (з 02.11.2019 по 28.03.2020) у ДЮСШ ХТЗ. Комплекси вправ були впровадженні в тренувальний процес спортсменів експериментальної групи.

Результати. Результати свідчать про статистично достовірні зміни тренувальних ефектів комплексів вправ на гнучкість хребта у спортсменів експериментальної групи ( $<<0,001)$. Спортсмени даної групи в середньому зменшили амплітуду руху штанги на 4,1 см, що дало їм змогу збільшити силові показники жиму лежачи.

Висновки. Після виконання комплексів вправ на гнучкість амплітуда руху штанги у спортсменів експериментальної групи статистично достовірно зменшилася, що позитивно вплинуло на показники жиму лежачи.

Ключові слова: пауерліфтинг, гнучкість, жим лежачи.
\end{abstract}

\section{Вступ}

Розвиток гнучкості хребта у спортсменів, які займаються пауерліфтингом, є необхідною умовою вдосконалення жиму, так як дозволяє зменшити розмах амплітуди між крайніми точками, а підйом штанги на меншу відстань значно полегшує підйом ваги (Шейко, 2005; Розгортуй, Товстоног, 2014; Остапенко, 2002).

При виконанні жиму використовується елемент техніки який називається міст (Літус, 2017; Шейко, 2005; Розторгуй, 2013а). Аналіз результатів дослідження свідчить про те, що якість техніки жиму лежачи залежить від рівня розвитку гнучкості хребта, збільшення рухливості плечових суглобів та покращення еластичності грудних м'язів (Загура, Розторгуй, \& Науменко, 2014; Стеценко \& Сікачина, 2004).

Вищевикладене свідчить про те, що техніка мосту $€$ важливим компонентом в жимі лежачи і покращення техніки для зменшення амплітуди руху штанги має важливе значення для спортсменів, бо полегшує роботу під час виконання вправи (Розторгуй, 2013b). Виявлено, що досліджувані спортсмени, для яких під час тренувань впроваджувалися комплекси вправ на гнучкість хребта та спеціальних вправ для виправлення помилок в

(c) Толубенко, Є., 2021. техніці жиму лежачи, зменшили амплітуду руху штанги та покращили техніку виконання вправи (Загура, Розторгуй, \& Науменко, 2014; Стеценко \& Сікачина, 2004). Отже, дослідження впливу засобів розвитку гнучкості на амплітуду руху штанги в жимі лежачи у спортсменів, які займаються пауерліфтингом, є актуальним.

Мета дослідження - визначити вплив засобів розвитку гнучкості на амплітуду руху штанги в жимі лежачи у спортсменів, які займаються пауерліфтингом.

\section{Матеріали і методи}

\section{Учасники дослідження}

У дослідженні взяли участь 20 спортсменів, які були поділені на дві групи: експериментальну та контрольну. У кожній групі по 10 спортсменів, які займаються пауерліфтингом - юнаки віком 19-20 років. Всі спортсмени займаються в одній группі та мають спортивні звання (КМС, МС та I розряд).

\section{Організачія дослідження}

Експеримент був проведений за на базі ДЮСШ «ХТЗ» і тривав протягом п'яти місяців( з 02.11.2019 по 28.03.2020). 
Для вирішення поставлених завдань були використані загальнонаукові методи дослідження. У роботі використано такі методи: спостереження, методи теоретичного аналізу та узагальнення, педагогічний експеримент, педагогічне тестування, методи математичного аналізу.

На початку експерименту були проведені заміри амплітуди руху штанги (відстань від штанги до найвищої точки грудної клітини) та розроблені два комплекси вправ: перший націлений на розвиток гнучкості хребта та еластичність грудних м язів, другий комплекс спеціальних вправ для виявлення індивідуальних помилок в техніці та їх виправлення.

Перший комплекс вправ на зменшення амплітуди руху штанги, спортсмени стабільно виконували 3 рази на тиждень після тренування або у вільний день від тренування протягом трьох місяців. Були підібрані гімнастичні вправи на покращення рухливості плечових суглобів та збільшення гнучкості хребта.

Другий комплекс спеціальних вправ, які спортсмени виконували під час тренування після жиму лежачи або після тренування 2 рази на тиждень.

Комплекс спрямований саме на покращення техніки, виявлення та виправлення розповсюджених помилок у техніці в жимі лежачи:

- Спортсмен не зводить лопатки, коли лягає на жимову лавку.

- Спортсмен зводить лопатки, але відпускає їх під час руху штанги вверх.

- Спортсмен не може утримати міст лежачи на жимовій лавці під час руху штанги

- Спортсмен не впирається ногами.

- Спортсмен не дає поштовху ногами під час руху штанги вверх.

- Вийшовши в міст на лавці спортсмен відриває сідниці(або відриває під час руху штанги вверх).

Через 5 місяців виконання комплексів спортсменами, були зняті остаточні заміри амплітуди руху штанги двох груп.

\section{Статистичний аналіз}

Дані були зібрані та організовані за допомогою EXCEL. Статистичний аналіз проводився за допомогою статистичного програмного пакету IBM SPSS Statistics 26. Обчислювались такі параметри: середнє арифметичне значення величини (X), стандартне відхилення, $\mathrm{t}$-критерій Стьюдента.

\section{Результати}

Отримані результати дозволяють стверджувати, що до початку першого етапу експерименту у контрольній та експериментальній групах техніка виконання вправи статистично достовірно не відрізнялася ( $>$ > 0,05)(таблиця).
Підсумкові результати, отримані після закінченні педагогічного експерименту свідчать про статистично достовірні зміни тренувальних ефектів комплексів вправ на гнучкість хребта у спортсменів експериментальної групи ( $\mathrm{p}<0,001)$. Спортсмени даної групи в середньому зменшили амплітуду руху штанги на 4,1 cм, що дало їм змогу збільшити силові показники жиму лежачи. Подібних змін у контрольній групі не відбулося (p > 0,05).

\section{Дискусія}

У роботі припускалося, що використання комплексів вправ спрямованих на розвиток гнучкості хребта та еластичність грудних м`язів та спеціальних вправ для виявлення індивідуальних помилок в техніці та їх виправлення будуть сприяти зменшенню ампплітуди руху штанги. Встановлено, що спортсмени експериментальної групи в середньому зменшили амплітуду руху штанги на 4.1 см, що дало їм змогу збільшити силові показники жиму лежачи.

Отримані дані доповнюють відомості про вдосконалення техніки виконання вправ в пауерліфтингу (Загура, Розторгуй, \& Науменко, 2014; Стеценко \& Сікачина, 2004), про те, що розвиток гнучкості хребта у спортсменів, $є$ необхідною умовою вдосконалення жиму, так як дозволяє зменшити розмах амплітуди між крайніми точками, а підйом штанги на меншу відстань значно полегшує підйом ваги (Шейко Б.І. 2007, Розгортуй М., Товстоног О. 2014), про особливості розвитку сили у спортсменів, які займаються пауерліфтингом (Rahmani, Samozino, Morin, \& Morel, 2018; Wilk, Golas, Krzysztofik, Nawrocka, \& Zajac, 2019; Wooten, Cherup, Mazzei, Patel, Mooney, Rafiq, \& Signorile, 2020).

Таким чином, відмічається позитивний вплив комплексів вправ на гнучкість на амплітуда руху штанги у спортсменів експериментальної групи.

\section{Висновки}

Аналіз результатів педагогічного експерименту дозволяє стверджувати, що після виконання комплексів вправ на гнучкість хребта та збільшення рухливості в плечових суглобах амплітуда руху штанги у спортсменів експериментальної групи значно зменшилася, ніж у спортсменів контрольної групи, які не виконували комплекси. Встановлено наявність достовірних відмінностей кінцевих результатів двох груп $(\mathrm{p}<0,001)$. Виконуючи два комплекси вправ спортсмени експериментальної групи в середньому зменшили амплітуду руху штанги на $1,27 \%$, контрольна група змінила свої результати на $0,13 \%$.

\section{Конфлікт інтересів}

Автор заявляє про відсутність конфлікту інтересів.

Таблиця 1. Результати порівняльного аналізу амплітуди руху у контрольній і експериментальній групі

\begin{tabular}{|c|c|c|c|c|c|c|c|c|}
\hline \multirow[t]{2}{*}{ Група } & \multirow[t]{2}{*}{$\mathbf{n}$} & \multicolumn{2}{|c|}{ До експеримента } & \multicolumn{2}{|c|}{ Після експеримента } & \multirow[t]{2}{*}{$\Delta \mathbf{x}$} & \multirow[t]{2}{*}{$\mathbf{t}$} & \multirow[t]{2}{*}{$\mathbf{p}$} \\
\hline & & $\mathbf{X}$ & $\mathbf{s}$ & $\mathbf{X}$ & $\mathbf{s}$ & & & \\
\hline КГ & 10 & 26,8 & 1,08 & 26,3 & 1,04 & 0,5 & 1,7 & $>0,05$ \\
\hline $\mathrm{E} \Gamma$ & 10 & 27 & 1,1 & 22,9 & 1,05 & 4,1 & 11,7 & $<0,001$ \\
\hline
\end{tabular}




\section{Література}

Шейко, Б. И. (2005). Пауэрлифтинг : [учебное пособие].М. : ЕАМ СПОРТ СЕРВИС. $544 \mathrm{c}$.

Розторгуй, М., \& Товстоног, О. (2014). Алгоритмізація навчання техніки змагальних вправ у силових видах спорту на етапі початкової підготовки. Фізична активність, здоров'я і спорт, 1(15), 38-45.

Остапенко, Л.А. (2002). Силовое троеборье: особенности тренировочного процесса на этапе отбора и начальной подготовки : учебн. пособ. М. : Физкультура и спорт, 150 с.

Літус, Р. I. (2017). Навчальна програма з фізичної культури профільного рівня для 10-11 класів, вид фізкультурної діяльності модуль Пауерліфтинг. Молодий вчений, 5 , 109-116.

Загура, Ф., Розторгуй, М., \& Науменко, В. (2014). Типові помилки техніки змагальних вправ у пауерліфтингу. Молода спортивна наука України : зб. наук. пр. з галузі фіз. виховання, спорту і здоров я людини, 18(1), 74-78.

Стеценко, А. І., \& Сікачина, М. О. (2004). Значення антропометричних показників спортсменів на формування техніки жиму штанги лежачи. Актуальні проблеми фізичної культури і спорту, 3, 123-125.

Розторгуй, М. (2013а). Алгоритм навчання техніці змагальних вправ пауерліфтерів на етапі початкової та попередньо базової підготовки. Спортивний вісник Придніпров'я, 3, 86-90.

Розторгуй, М. С. (2013b). Експериментальне обгрунтування алгоритму навчання техніці змагальних вправ пауерліфтерів. Вісник Чернігівського національного педагогічного університету. Сер.: Педагогічні науки. Фізичне виховання та спорт, 112(4), 210-213.

Rahmani, A., Samozino, P., Morin, J.-B., \& Morel, B. (2018). A simple method for assessing upper-limbforce-velocity profile in bench press. International Journal of Sports Physiology andPerformance, 13(2), 200-207. Scopus. https://doi.org/10.1123/ijspp.2016-0814

Wilk, M., Golas, A., Krzysztofik, M., Nawrocka, M., \& Zajac, A. (2019). The effects of eccentric cadence on power and velocity of the bar during the concentric phase of the bench press movement. Journal of Sports Science and Medicine, 18(2), 191-197. Scopus.

Wooten, S. V., Cherup, N., Mazzei, N., Patel, S., Mooney, K., Rafiq, A., \& Signorile, J. F. (2020). Yoga Breathing Techniques Have No Impact on Isokinetic and Isoinertial Power. Journal of strength and conditioning research, 34(2), 430-439. Scopus. https://doi.org/10.1519/ JSC.0000000000002771

\section{References}

Sheiko, B. I. (2005). Pauerlifting : [uchebnoe posobie].M. : EAM SPORT SERVIS. $544 \mathrm{~s}$.

Roztorhui, M., \& Tovstonoh, O. (2014). Alhorytmizatsiia navchannia tekhniky zmahalnykh vprav u sylovykh vydakh sportu na etapi pochatkovoi pidhotovky. Fizychna aktyvnist, zdorovia i sport, 1(15), 38-45.

Ostapenko, L.A. (2002). Sylovoe troebore: osobennosty trenyrovochnoho protsessa na эtape otbora y nachalnoi podhotovky : uchebn. posob. M. : Fyzkultura y sport, $150 \mathrm{~s}$.

Litus, R. I. (2017). Navchalna prohrama z fizychnoi kultury profilnoho rivnia dlia 10-11 klasiv, vyd fizkulturnoi diialnosti modul Pauerliftynh. Molodyi vchenyi, 5 , 109116.

Zahura, F., Roztorhui, M., \& Naumenko, V. (2014). Typovi pomylky tekhniky zmahalnykh vprav u pauerliftynhu. Moloda sportyvna nauka Ukrainy : zb. nauk. pr. z haluzi fiz. vykhovannia, sportu i zdorovia liudyny, 18(1), 74-78.

Stetsenko, A. I., \& Sikachyna, M. O. (2004). Znachennia antropometrychnykh pokaznykiv sportsmeniv na formuvannia tekhniky zhymu shtanhy lezhachy. Aktualni problemy fizychnoi kultury i sportu, 3, 123-125.

Roztorhui, M. (2013a). Alhorytm navchannia tekhnitsi zmahalnykh vprav pauerlifteriv na etapi pochatkovoi ta poperedno bazovoi pidhotovky. Sportyvnyi visnyk Prydniprovia, 3, 86-90.

Roztorhui, M. S. (2013b). Eksperymentalne obgruntuvannia alhorytmu navchannia tekhnitsi zmahalnykh vprav pauerlifteriv. Visnyk Chernihivskoho natsionalnoho pedahohichnoho universytetu. Ser.: Pedahohichni nauky. Fizychne vykhovannia ta sport, 112(4), 210-213.

Rahmani, A., Samozino, P., Morin, J.-B., \& Morel, B. (2018). A simple method for assessing upper-limbforce-velocity profile in bench press. International Journal of Sports Physiology andPerformance, 13(2), 200-207. Scopus. https://doi.org/10.1123/ijspp.2016-0814

Wilk, M., Golas, A., Krzysztofik, M., Nawrocka, M., \& Zajac, A. (2019). The effects of eccentric cadence on power and velocity of the bar during the concentric phase of the bench press movement. Journal of Sports Science and Medicine, 18(2), 191-197. Scopus.

Wooten, S. V., Cherup, N., Mazzei, N., Patel, S., Mooney, K., Rafiq, A., \& Signorile, J. F. (2020). Yoga Breathing Techniques Have No Impact on Isokinetic and Isoinertial Power. Journal of strength and conditioning research, 34(2), 430-439. Scopus. https://doi.org/10.1519/ JSC.0000000000002771 


\section{DEVELOPMENT OF SPINE FLEXIBILITY IN POWERLIFTING ATHLETES}

\section{Yelyzaveta Tolubenko ${ }^{1 \mathrm{ABCD}}$}

\section{${ }^{1}$ H. S. Skovoroda Kharkiv National Pedagogical University}

Authors' Contribution: A - Study design; B - Data collection; C - Statistical analysis; D - Manuscript Preparation; E - Funds Collection

Report. Article: 3 p., 1 tabl., 11 sources.

The purpose of the study was to determine the influence of movement amplitude on the bench press results in powerlifting athletes.

Materials and methods. The study involved two groups of 10 athletes engaged in powerlifting - young men aged 19-20. The study used the following methods: observation, methods of theoretical analysis and generalization, pedagogical experiment, pedagogical testing, methods of mathematical statistics.

The research lasted five months (from November 2, 2019 to March 28, 2020) at the KhTP Children and Youth Sports School. Sets of exercises were introduced into the training process of the experimental group athletes.
Results. The results show statistically significant changes in the training effects of sets of spine flexibility exercises in the experimental group athletes $(\mathrm{p}<0.001)$. The athletes of this group reduced the amplitude of the barbell movement on average by $4.1 \mathrm{~cm}$, which enabled them to increase the bench press strength indicators.

Conclusions. After performing sets of flexibility exercises, the amplitude of the barbell movement in the experimental group athletes reduced statistically significantly, which positively influenced the bench press indicators.

Keywords: powerlifting, flexibility, bench press.

\section{Information about the authors:}

Tolubenko Yelyzaveta: tolubenko.52@gmail.com; https://orcid.org/0000-0001-9535-6664; Department of Theory and Methodology of Physical Education, H. S. Skovoroda Kharkiv National Pedagogical University, Alchevskykh St, 29, Kharkiv, 61002, Ukraine.

Cite this article as: Tolubenko, Ye. (2021). Development of Spine Flexibility in Powerlifting Athletes. Journal of Learning Theory and Methodology, 1(2), 29-32. https://doi.org/10.17309/jltm.2021.1.04

Received: 27.11.2020. Accepted: 20.02.2021. Published: 28.02.2021

This work is licensed under a Creative Commons Attribution 4.0 International License (http://creativecommons.org/licenses/by/4.0). 